\title{
Iriomoteolides-10a and 12a, Cytotoxic Macrolides from Marine Dinoflagellate Amphidinium Species
}

\author{
Mai Akakabe, ${ }^{a, \dagger}$ Keiko Kumagai, ${ }^{a}$ Masayuki Tsuda, ${ }^{a}$ Yuko Konishi, ${ }^{a}$ Akira Tominaga,${ }^{b}$ \\ Daisuke Kaneno, ${ }^{c}$ Eri Fukushi, ${ }^{d}$ Jun Kawabata, ${ }^{d}$ Atsunori Masuda, ${ }^{e,+}$ and Masashi Tsuda* $f$ \\ ${ }^{a}$ Science Research Center, Kochi University; B200 Monobe, Nankoku, Kochi 783-8505, Japan: ${ }^{b}$ Graduate School of \\ Kuroshio Science and Kochi Medical School, Kochi University; B200 Monobe, Nankoku, Kochi 783-8505, Japan: \\ ${ }^{c}$ Research Faculty of Agriculture, Hokkaido University; Sapporo 060-8589, Japan: ${ }^{d}$ Faculty of Science, Kochi \\ University; Kochi 780-8520, Japan: ${ }^{e}$ Yanmar Environmental Sustainability Support Association; Osaka 530-0014, \\ Japan: and ${ }^{f}$ Center for Advanced Marine Core Research, Kochi University; B200 Monobe, Nankoku, Kochi \\ 783-8505, Japan.
}

Received January 9, 2016; accepted April 11, 2016

Two new macrolides, iriomoteolides-10a (1) and -12a (2), have been isolated from a marine dinoflagellate Amphidinium sp. (KCA09053 strain), and their structures were elucidated on the basis of a detailed two dimensional (2D)-NMR analysis. Compound 1 is a novel 21-membered Amphidinium macrolide, which contains one tetrahydrofuran ring, two ketone carbonyls, two hydroxyl groups, and six one-carbon branches. Compound 2 is a new 12-membered macrolide related to amphidinolide Q. Compound 1 exhibited cytotoxic activity against human cervix adenocarcinoma HeLa and murine hepatocellular carcinoma MH134 cells.

Key words macrolide; dinoflagellate; Amphidinium; cytotoxic activity

Marine dinoflagellates of the genus Amphidinium have been proven to produce unique polyketide-like metabolites with interesting biological activities. ${ }^{1)}$ A series of macrolides, represented by amphidinolides, are well-known secondary metabolites of Amphidinium dinoflagellates ${ }^{2,3)}$ with various carbon skeletons forming 12-29-membered (including odd-numbered) macrolactone rings and biosynthetically unique partial structures such as vicinally located $\mathrm{C}_{1}$ branches. During our investigation of bioactive Amphidinium metabolites, ${ }^{4,5)}$ we have recently reported the isolation of 22- and 23-membered Amphidinium macrolides, i.e., iriomoteolides-13a ${ }^{6)}$ and $-2 \mathrm{a}^{7)}$ respectively, from the marine benthic dinoflagellate Amphidinium species (KCA09053 and HYA024 strains, respectively). Further investigation of the cytotoxic fractions of KCA09053 strain led to the discovery of the first 21-membered Amphidinium macrolide, iriomoteolide-10a (1), together with a new 12-membered macrolide, iriomoteolide-12a (2) (Fig. 1). Herein, we describe the isolation and structural elucidation of $\mathbf{1}$ and $\mathbf{2}$.

\section{Results and Discussion}

The dinoflagellate Amphidinium sp. (strain KCA09053) was cultivated at $25^{\circ} \mathrm{C}$ for 2 weeks in seawater medium under illumination. The algal cells were extracted with methanol $(\mathrm{MeOH})$-toluene $(3: 1)$. The toluene-soluble materials of the extract were subjected to cytotoxic assay-guided fractionation using a silica gel column with chloroform $\left(\mathrm{CHCl}_{3}\right)-\mathrm{MeOH}$. One of the cytotoxic fractions was separated with an octadecylsilyl (ODS) column followed by reversed-phase HPLC to afford iriomoteolide-10a (1, 0.069\% from dry weight). On the other hand, iriomoteolide-12a (2) was obtained from the less

† Present address: Synthetic Organic Chemistry Laboratory, RIKEN; 2-1 Hirosawa, Wako, Saitama 351-0198, Japan.

*Present address: College of Agriculture, Tamagawa University; Machida, Tokyo 194-861, Japan. polar fraction of the first silica gel column chromatography (CC) in $0.016 \%$ yield. Known macrolides, iriomoteolides- $1 \mathrm{a},{ }^{8)}$ $\left.-3 a,{ }^{9}\right)$ and $-13 a,{ }^{6}$ have been separated by the first $\mathrm{SiO}_{2}$ gel column from a more polar fraction than those containing $\mathbf{1}$ and $\mathbf{2}$.

Iriomoteolide-10a (1) was obtained as optically active and colorless amorphous solid, and the molecular formula of $\mathrm{C}_{35} \mathrm{H}_{60} \mathrm{O}_{7}$ was revealed by electrospray ionization (ESI)-MS data $\left(m / z \quad 615.4315 \quad[\mathrm{M}+\mathrm{Na}]^{+}, \Delta+0.1 \mathrm{mmu}\right)$. The ${ }^{13} \mathrm{C}-\mathrm{NMR}$ spectrum in benzene- $d_{6}\left(\mathrm{C}_{6} \mathrm{D}_{6}\right)$ (Table 1$)$ showed the 35 carbon resonances, and their chemical shifts and multiplicities assigned by heteronuclear multiple quantum coherence (HMQC) and $\mathrm{CH}_{2}$-selected heteronuclear single quantum coherence

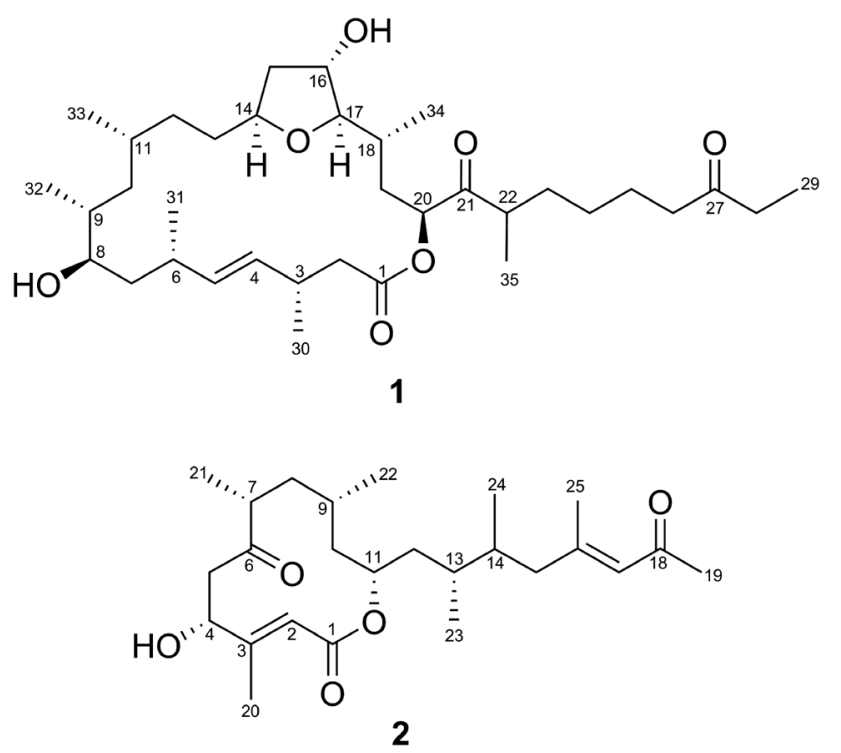

Fig. 1. Structures of Iriomoteolides-10a (1) and -12a (2)

C-3, C-6, C-8, C-9 and C-11 and C-14, C-16, C-17, C-18, and C-20 of 1 were independently relative.

* To whom correspondence should be addressed. e-mail: mtsuda@kochi-u.ac.jp 
Table 1. ${ }^{1} \mathrm{H}$ - and ${ }^{13} \mathrm{C}-\mathrm{NMR}$ Data for Iriomoteolide-10a (1) in $\mathrm{C}_{6} \mathrm{D}_{6}$

\begin{tabular}{|c|c|c|c|c|c|}
\hline Position & ${ }^{13} \mathrm{C}$ & ${ }^{1} \mathrm{H}$ (mult, $J=$ in $\mathrm{Hz}$ ) & Position & ${ }^{13} \mathrm{C}$ & ${ }^{1} \mathrm{H}$ (mult, $J=$ in $\mathrm{Hz}$ ) \\
\hline 1 & $171.3 \mathrm{C}$ & & 17 & $90.6 \mathrm{CH}$ & $3.77 \mathrm{dd}, 7.0,2.8$ \\
\hline \multirow[t]{2}{*}{2} & \multirow{2}{*}{$42.9 \mathrm{CH}_{2}$} & $2.36 \mathrm{dd}, 14.0,4.7$ & 18 & $34.5 \mathrm{CH}$ & $1.94 \mathrm{~m}$ \\
\hline & & $2.21 \mathrm{dd}, 14.0,9.8$ & 19 & $33.1 \mathrm{CH}_{2}$ & $2.03 \mathrm{ddd}, 15.0,9.7,3.3$ \\
\hline 3 & $34.3 \mathrm{CH}$ & $2.78 \mathrm{~m}$ & & & $1.58 \mathrm{ddd}, 15.0,10.0,3.1$ \\
\hline 4 & $133.7 \mathrm{CH}$ & $5.50 \mathrm{dd}, 15.0,7.2$ & 20 & $75.3 \mathrm{CH}$ & $5.37 \mathrm{dd}, 9.7,3.1$ \\
\hline 5 & $135.4 \mathrm{CH}$ & $5.30 \mathrm{dd}, 15.0,8.6$ & 21 & $210.0 \mathrm{C}$ & \\
\hline 6 & $34.1 \mathrm{CH}$ & $2.54 \mathrm{~m}$ & 22 & $42.8 \mathrm{CH}$ & $2.61 \mathrm{~m}$ \\
\hline 7 & $38.7 \mathrm{CH}_{2}$ & $\begin{array}{l}1.43 \mathrm{~m} \\
1.27 \mathrm{~m}\end{array}$ & 23 & $32.5 \mathrm{CH}_{2}$ & $\begin{array}{l}1.95 \mathrm{~m} \\
1.17 \mathrm{~m}\end{array}$ \\
\hline 8 & $71.8 \mathrm{CH}$ & $3.74 \mathrm{ddd}, 9.8,3.5,1.8$ & 24 & $37.2 \mathrm{CH}_{2}$ & $1.11^{a)} \mathrm{m}$ \\
\hline 9 & $37.1 \mathrm{CH}$ & $1.81 \mathrm{~m}$ & 25 & $23.8 \mathrm{CH}_{2}$ & $1.51 \mathrm{~m}$ \\
\hline \multirow[t]{2}{*}{10} & \multirow[t]{2}{*}{$41.5 \mathrm{CH}_{2}$} & $1.41 \mathrm{~m}$ & & & $1.34 \mathrm{~m}$ \\
\hline & & $0.96 \mathrm{~m}$ & 26 & $41.7 \mathrm{CH}_{2}$ & $1.92^{a)} \mathrm{t}, 7.0$ \\
\hline 11 & $31.3 \mathrm{CH}$ & $1.49 \mathrm{~m}$ & 27 & $210.1 \mathrm{C}^{2}$ & \\
\hline \multirow[t]{2}{*}{12} & \multirow[t]{2}{*}{$33.6 \mathrm{CH}_{2}$} & $1.52 \mathrm{~m}$ & 28 & $35.7 \mathrm{CH}_{2}$ & $1.91^{a)} \mathrm{q}, 7.0$ \\
\hline & & $1.20 \mathrm{~m}$ & 29 & $7.9 \mathrm{CH}_{3}$ & $0.94^{b)}$ t, 7.0 \\
\hline \multirow[t]{2}{*}{13} & \multirow[t]{2}{*}{$34.5 \mathrm{CH}_{2}$} & $1.57 \mathrm{~m}$ & 30 & $20.5 \mathrm{CH}_{3}$ & $0.98^{b)} \mathrm{d}, 7.0$ \\
\hline & & $1.54 \mathrm{~m}$ & 31 & $22.6 \mathrm{CH}_{3}$ & $1.10^{b)} \mathrm{d}, 7.0$ \\
\hline 14 & $78.1 \mathrm{CH}$ & $4.17 \mathrm{~m}$ & 32 & $15.2 \mathrm{CH}_{3}$ & $0.99^{b)} \mathrm{d}, 7.0$ \\
\hline \multirow[t]{2}{*}{15} & \multirow[t]{2}{*}{$41.8 \mathrm{CH}_{2}$} & $1.84 \mathrm{~m}$ & 33 & $20.6 \mathrm{CH}_{3}$ & $0.92^{b)} \mathrm{d}, 7.0$ \\
\hline & & $1.64 \mathrm{ddd}, 14.5,8.0,6.6$ & 34 & $16.5 \mathrm{CH}_{3}$ & $1.15^{b)} \mathrm{d}, 7.0$ \\
\hline 16 & $74.0 \mathrm{CH}$ & 4.12 ddd, $7.0,6.6,3.5$ & 35 & $17.9 \mathrm{CH}_{3}$ & $1.22^{b)} \mathrm{d}, 7.0$ \\
\hline
\end{tabular}

a) $2 \mathrm{H}$. b) $3 \mathrm{H}$.

(HSQC) spectra indicated the presence of 2 ketones, 1 ester carboxyl, 13 methines including two $s p^{2}$ ones, 12 methylenes, and 7 methyl carbons. One olefin and three carbonyl groups accounted for four out of the six degrees of unsaturation; thus, the remaining double bond equivalents were attributed to the presence of two rings in the molecule of $\mathbf{1}$.

The planar structure of $\mathbf{1}$ was elucidated on the basis of detailed NMR studies, namely ${ }^{1} \mathrm{H}-{ }^{1} \mathrm{H}$ correlated spectroscopy (COSY), total correlation spectroscopy (TOCSY), heteronuclear multiple bond correlation (HMBC), and $\mathrm{CH}_{2}$-selected HSQC-TOCSY spectra measured in benzene- $d_{6} \cdot{ }^{1} \mathrm{H}-{ }^{1} \mathrm{H}$ COSY and TOCSY spectra revealed three ${ }^{1} \mathrm{H}-{ }^{1} \mathrm{H}$ networks from $\mathrm{H}_{2}-2$ to $\mathrm{H}-20, \mathrm{H}_{3}-30, \mathrm{H}_{3}-31, \mathrm{H}_{3}-32, \mathrm{H}_{3}-33$, and $\mathrm{H}_{3}-34$, from $\mathrm{H}-22$ to $\mathrm{H}_{2}-26$ and $\mathrm{H}_{3}-35$, and from $\mathrm{H}_{2}-28$ to $\mathrm{H}_{3}-29$ (Fig. 2). The E-geometry was assigned to the disubstituted C-4-C-5 double bond, as suggested by the $J(\mathrm{H}-4 / \mathrm{H}-5)$ value $(15.0 \mathrm{~Hz})$. The long-range ${ }^{1} \mathrm{H}-{ }^{13} \mathrm{C}$ correlations for $\mathrm{H}_{2}-26\left(\delta_{\mathrm{H}} 1.92\right) / \mathrm{C}-24$ $\left(\delta_{\mathrm{C}} 37.2\right)$ and $\mathrm{H}_{3}-35\left(\delta_{\mathrm{H}} 1.22\right) / \mathrm{C}-24$ observed in $\mathrm{CH}_{2}$-selected HSQC-TOCSY spectrum supported an aliphatic substructure for the C-22-C-26 portion. HMBC correlations from $\mathrm{H}-20\left(\delta_{\mathrm{H}}\right.$ 5.37) and $\mathrm{H}_{3}-35$ to a ketone carbonyl (C-21: $\left.\delta_{\mathrm{C}} 210.0\right)$ and from $\mathrm{H}_{2}-26\left(\delta_{\mathrm{H}} 1.92\right)$ and $\mathrm{H}_{3}-29\left(\delta_{\mathrm{H}} 0.94\right)$ to another ketone carbonyl $\left(\mathrm{C}-27: \delta_{\mathrm{C}} 210.1\right)$ suggested that the ketone groups connect $\mathrm{C}-20$ to $\mathrm{C}-22$ and $\mathrm{C}-26$ to $\mathrm{C}-28$. The HMBC correlation for $\mathrm{H}-17\left(\delta_{\mathrm{H}}\right.$ $3.77) / \mathrm{C}-14\left(\delta_{\mathrm{C}} 78.1\right)$ revealed the presence of a tetrahydrofuran ring at $\mathrm{C}-14-\mathrm{C}-17$. The ester linkage between $\mathrm{C}-1$ and $\mathrm{C}-20$ was established by the HMBC correlations for $\mathrm{H}_{2}-2\left(\delta_{\mathrm{H}} 2.36\right.$ and 2.21$) / \mathrm{C}-1\left(\delta_{\mathrm{C}} 171.3\right)$ and $\mathrm{H}-20 / \mathrm{C}-1$. Thus, the gross structure of 1 was concluded to contain a 21-membered macrolactone ring, as shown in Fig. 1.

The relative stereochemistry of $\mathbf{1}$ was investigated on the basis of nuclear Overhauser effect spectroscopy (NOESY) correlations and coupling constants. Magnitude of the ${ }^{1} \mathrm{H}-{ }^{1} \mathrm{H}$ couplings was estimated from the intensity of the ${ }^{1} \mathrm{H}-{ }^{1} \mathrm{H}$

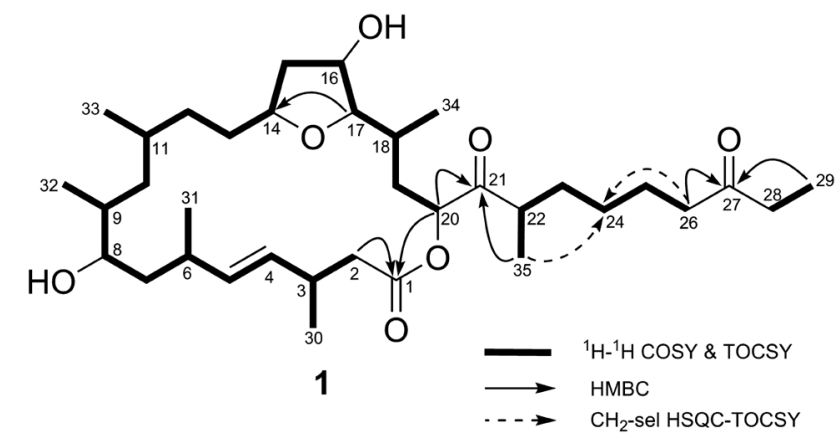

Fig. 2. Selected 2D-NMR Correlations for Iriomoteolide-10a (1)

COSY correlations, when signals overlapped with other signals or showed multiple couplings. The $J$-based configuration analysis $^{10)}$ was applied to the investigation of C-8-C-9 and $\mathrm{C}-17-\mathrm{C}-18$ bonds. Long-range ${ }^{13} \mathrm{C}-{ }^{1} \mathrm{H}$ coupling constants were obtained from analyses of the hetero half-filtered TOCSY (HETLOC) correlations or from the cross-peak intensities in the phase-sensitive HMBC spectrum.

The antiperiplanar relationship for $\mathrm{H}-3-\mathrm{H}-4$ and $\mathrm{H}-5-\mathrm{H}-6$ was deduced from NOESY correlations for $\mathrm{H}-3 / \mathrm{H}-5$ and $\mathrm{H}-4 / \mathrm{H}-6$ and from the relatively large $J(\mathrm{H}-3 / \mathrm{H}-4)(7.2 \mathrm{~Hz})$ and $J(\mathrm{H}-5 / \mathrm{H}-6)$ values $(8.6 \mathrm{~Hz})$, thus suggesting an equatorial orientation for both $\mathrm{C}-30$ and $\mathrm{C}-31$ methyl groups (Fig. 3a). The 1,3-syn relation for $\mathrm{C}-31$ and $8-\mathrm{OH}$ was indicated by the coupling constants for H-6/H-7a $(>8 \mathrm{~Hz}), \mathrm{H}-6 / \mathrm{H}-7 \mathrm{~b}(<4 \mathrm{~Hz})$, $\mathrm{H}-7 \mathrm{a} / \mathrm{H}-8(9.8 \mathrm{~Hz})$, and $\mathrm{H}-7 \mathrm{~b} / \mathrm{H}-8(3.5 \mathrm{~Hz})$, and by NOESY correlations for $\mathrm{H}-5 / \mathrm{H}-7 \mathrm{~b}$ and $\mathrm{H}-5 / \mathrm{H}-8$. Considering the coupling constants for $\mathrm{H}-8 / \mathrm{H}-9$ (1.8 Hz), C-8/H-9 (-1 Hz), C- $10 / \mathrm{H}-8$ $(<3 \mathrm{~Hz})$, and $\mathrm{C}-32 / \mathrm{H}-8(<6 \mathrm{~Hz})$, the $\mathrm{C}-8-\mathrm{C}-9$ bond was suggested to have the threo configuration (Fig. 3b). The NOESY correlation observed for $\mathrm{H}-8 / \mathrm{H}-11$ indicated that the methine 
(a)

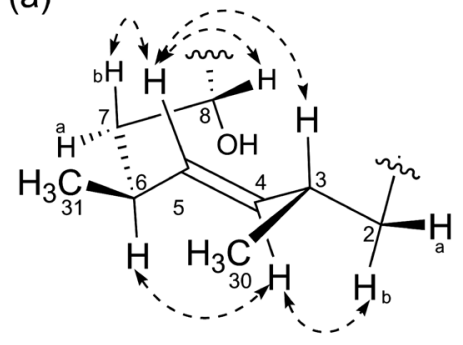

(b)

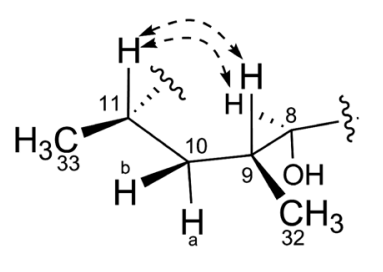

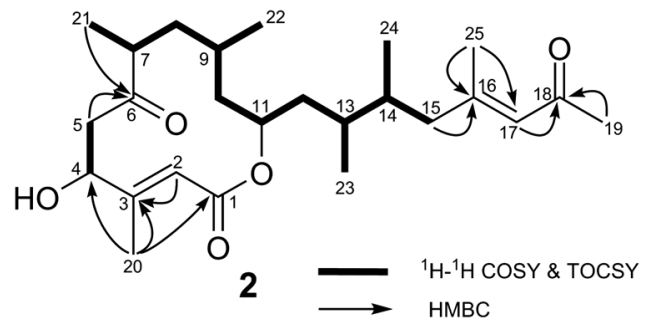

Fig. 4. Selected 2D-NMR Correlations for Iriomoteolide-12a (2) (c)

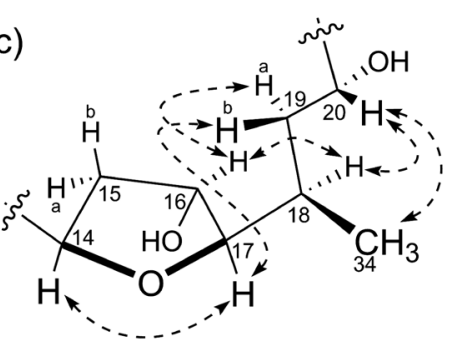

$\leftrightarrow$ NOESY

Fig. 3. Stereostructures for (a) C-2-C-8, (b) C-8-C-11, and (c) C14-C-20 Portions in Iriomoteolide-10a (1)

"a" and "b" for germinal proton pairs denoted low-and high-field resonances, respectively. ${ }^{1} \mathrm{H}-{ }^{1} \mathrm{H}$ coupling constants $(\mathrm{Hz})(\mathrm{H} / \mathrm{H}): 4.7(2 \mathrm{a} / 3), 9.8(2 \mathrm{~b} / 3), 7.2(3 / 4), 7.0$ (3/30), 15.0 (4/5), $8.6(5 / 6),>8$ (6/7a), <4 (6/7b), $7.0(6 / 31), 9.8(7 \mathrm{a} / 8), 3.5(7 \mathrm{~b} / 8), 1.8$ $(8 / 9),>8(9 / 10 \mathrm{a}),<4(9 / 10 \mathrm{~b}), 7.0(9 / 32),>8(10 \mathrm{a} / 11),<4(10 \mathrm{~b} / 11), 7.0(11 / 33),<4$ (14/15a), 8.0 (14/15b), 3.5 (15a/16), 6.6 (15b/16), 7.0 (16/17), 2.8 (17/18), 3.3 (18/19a), $10.0(18 / 19 \mathrm{~b}), 7.0(18 / 34), 9.7(19 \mathrm{a} / 20), 3.1(19 \mathrm{~b} / 20) .{ }^{13} \mathrm{C}-{ }^{1} \mathrm{H}$ coupling constants $(\mathrm{Hz})$ $(\mathrm{C} / \mathrm{H}):-1(8 / 9),<3$ (10/8), ca. 0 (17/18), 6 (19/17), <6 (32/8), 2 (34/17).

proton of C-8 was oriented toward the inside of the macrocyclic ring. The relatively large $J(\mathrm{H}-9 / \mathrm{H}-10 \mathrm{a})$ and $J(\mathrm{H}-10 \mathrm{a} / \mathrm{H}-11)$ values (both $>8 \mathrm{~Hz}$ ) were deduced to be an antiperiplanar relationship between these protons and an equatorial orientation for both C-32 and C-33 methyl groups, which was corroborated by the NOESY correlation for $\mathrm{H}-9 / \mathrm{H}-11$.

For the tetrahydrofuran portion at C-14-C-17 (Fig. 3c), NOESY correlations for $\mathrm{H}-14 / \mathrm{H}-17$ and $\mathrm{H}-16 / \mathrm{H}-18$ revealed syn and anti configurations for $\mathrm{H}-14-\mathrm{H}-17$ and $\mathrm{H}-16-\mathrm{H}-17$, respectively. The erythro configuration of the $\mathrm{C}-17-\mathrm{C}-18$ bond was elucidated from the coupling constants of $\mathrm{H}-17 / \mathrm{H}-18$ (2.8 Hz), C-17/H-18 (ca. 0 Hz), C-19/H-17 (6 Hz), and C-34/H-17 $(2 \mathrm{~Hz})$. The anti relations for $\mathrm{H}-18-\mathrm{H}-19 \mathrm{~b}$ and $\mathrm{H}-19 \mathrm{a}-\mathrm{H}-20$ were implied by their relatively large coupling constants (10.0, 9.7 Hz, respectively). Moreover, a 1,3-syn configuration for the C-18-C-20 portion was suggested by NOESY correlations for H-16/H-18, H-16/H-19a, H-17/H-19b, H-18/H-20, and H-20/ $\mathrm{H}_{3}$-34. On the other hand, the stereochemical relationship between $\mathrm{C}-20$ and $\mathrm{C}-22$ through the $\mathrm{C}-21$ ketone could not be determined, although NOESY correlations were found for $\mathrm{H}-20 / \mathrm{H}-22, \mathrm{H}-20 / \mathrm{H}-23 \mathrm{~b}$, and $\mathrm{H}-20 / \mathrm{H}_{3}-35$. In addition, because of the overlap between $\mathrm{H}-12 \mathrm{a}$ and $\mathrm{H}_{2}-13$, the relative stereochemistry between $\mathrm{C}-11$ and $\mathrm{C}-14$ could not be unambiguously assigned. In order to determine the absolute configuration at C-8 and C-16, the modified Mosher's method was applied using a small amount of $\mathbf{1}$; however, $\mathbf{1}$ decomposed in the reaction with $\alpha$-methoxy- $\alpha$-trifluormethyphenylacetyl chloride (MTPACl).

The molecular formula, $\mathrm{C}_{25} \mathrm{H}_{40} \mathrm{O}_{5}$, of iriomotrolide-12a (2) was established by ESI-MS $\left(\mathrm{m} / z\right.$ 443.2768 $[\mathrm{M}+\mathrm{Na}]^{+}, \Delta+0.0$ $\mathrm{mmu})$. The ${ }^{13} \mathrm{C}-\mathrm{NMR}$ spectrum in chloroform- $d_{1}\left(\mathrm{CDCl}_{3}\right)$ disclosed the presence of a total of 25 carbon signals due to 2 ketones, 1 ester carbonyl, $2 s p^{2}$ quaternary carbons, 2 $s p^{2}$ methines, $6 s p^{3}$ methines including 2 oxygenated ones, $5 s p^{3}$ methylenes, and 7 methyl groups. The ${ }^{1} \mathrm{H}-\mathrm{NMR}$ spectrum showed the presence of two singlet $s p^{2}$ methines $[\delta$ $5.99(\mathrm{H}-17), 5.89(\mathrm{H}-2)]$ and three singlet methyl groups $[\delta$ $2.12\left(\mathrm{H}_{3}-19\right), 2.07\left(\mathrm{H}_{3}-20\right)$, and $\left.2.06\left(\mathrm{H}_{3}-25\right)\right]$, all presumably adjacent to quaternary carbons. ${ }^{1} \mathrm{H}-{ }^{1} \mathrm{H}$ COSY and TOCSY spectra revealed two ${ }^{1} \mathrm{H}-{ }^{1} \mathrm{H}$ networks from $\mathrm{H}-4$ to $\mathrm{H}_{2}-5$ and from $\mathrm{H}-7$ to $\mathrm{H}_{2}-15, \mathrm{H}_{3}-21, \mathrm{H}_{3}-22, \mathrm{H}_{3}-23$, and $\mathrm{H}_{3}-24$ (Fig. 4). $\mathrm{HMBC}$ correlations for $\mathrm{H}-2 / \mathrm{C}-3\left(\delta_{\mathrm{C}} 154.9\right), \mathrm{H}_{3}-20 / \mathrm{C}-3$, and $\mathrm{H}_{3}-$ $20 / \mathrm{C}-4\left(\delta_{\mathrm{C}} 73.1\right)$ indicated that $\mathrm{C}-2$ and $\mathrm{C}-20$ were connected to $\mathrm{C}-4$ through the $s p^{2}$ quaternary carbon $\mathrm{C}-3$. The presence of a ketone carbonyl at C- 6 was implied by $\mathrm{HMBC}$ correlations for $\mathrm{H}_{2}-5\left(\delta_{\mathrm{H}} 3.02,2.48\right) / \mathrm{C}-6\left(\delta_{\mathrm{C}} 217.0\right)$ and $\mathrm{H}_{3}-21\left(\delta_{\mathrm{H}} 1.03\right) / \mathrm{C}-6$. Attachment of a pent-2-en-3-one terminus at $\mathrm{C}-15$ was deduced from $\mathrm{HMBC}$ correlations for $\mathrm{H}_{2}-15\left(\delta_{\mathrm{H}} 2.07,1.84\right) / \mathrm{C}-16$ $\left(\delta_{\mathrm{C}} 157.9\right), \mathrm{H}-17 / \mathrm{C}-18\left(\delta_{\mathrm{C}} 198.7\right), \mathrm{H}_{3}-19 / \mathrm{C}-18, \mathrm{H}_{3}-25 / \mathrm{C}-16$, and $\mathrm{H}_{3}-25 / \mathrm{C}-17$. The $E$-geometries for the two trisubstituted double bonds at C-2-C-3 and C-16-C-17 were inferred from the ${ }^{13} \mathrm{C}$ chemical shifts of the C-20 and C-25 methyl groups $\left(\delta_{\mathrm{C}} 16.8\right.$, 14.7, respectively). A four-bond $\mathrm{HMBC}$ correlation was observed from $\mathrm{H}_{3}-20$ to $\mathrm{C}-1\left(\delta_{\mathrm{C}} 167.7\right)$, thus indicating that an ester carbonyl was attached to $\mathrm{C}-2$. The relatively low-field resonance for the oxymethine $\mathrm{H}-11\left(\delta_{\mathrm{H}}\right.$ 5.06) suggested that $\mathrm{C}-11$ was involved in an ester linkage with $\mathrm{C}-1$. Thus, the planar structure of $\mathbf{2}$ was found to consist of a 12-membered macrolide associated with two $\alpha, \beta$-unsaturated carbonyls, a saturated ketone, six $\mathrm{C}_{1}$ branches, and a hydroxyl group. Moreover, the gross structure of the macrocyclic portion of 2 corresponded to that of amphidinolide $\mathrm{Q}^{11-13)}$ (3), a known 12-membered macrolide.

In order to elucidate the stereochemistry of 2 , the ${ }^{13} \mathrm{C}$ chemical shifts of $\mathbf{2}$ in $\mathrm{CDCl}_{3}$ were compared with the data reported $^{12)}$ for 3 . Figure 5 shows the absolute values of chemical shift differences $\left[\Delta \delta\right.$ (in ppm) $=\delta\left(2\right.$ in $\left.\mathrm{CDCl}_{3}\right)-\delta(3$ in $\left.\mathrm{CDCl}_{3}\right)$ ] for $\mathrm{C}-1-\mathrm{C}-13$ and four branched methyl groups at $\mathrm{C}-3, \mathrm{C}-7, \mathrm{C}-9$, and $\mathrm{C}-13$. The absolute $\Delta \delta$ values for $\mathrm{C}-1-\mathrm{C}-11$ and methyls at C-3, C-7, and C-9 were extremely small $(\leq 0.2 \mathrm{ppm})$, strongly suggesting that the relative stereochemistries for C-4, C-7, C-9, and C-11 in the macrolactone ring of 2 were the same as those of $\mathbf{3}$. On the other hand, because of side-chain structural differences between $\mathbf{2}$ and $\mathbf{3}$, the $\Delta \delta$ values for $\mathrm{C}-12, \mathrm{C}-13$, and 13-Me were high. $\mathrm{C}-11$ and $\mathrm{C}-13$ of 2 were assumed to take a syn configuration, as that in $\mathbf{3}$, because the strongly coupled signal for $\mathrm{H}_{2}-12\left[\delta_{\mathrm{H}} 1.42(2 \mathrm{H})\right]$ of 2 was reminiscent of the signal pattern of $3 .{ }^{12}$ ) Moreover, the optical rotation $\left([\alpha]_{\mathrm{D}}\right)$ of $\mathbf{2}$ showed the same sign and similar magnitude as that reported for $\mathbf{3}$, presumably indicating that the absolute stereochemistries for C-4, C-7, C-9, C-11, and 


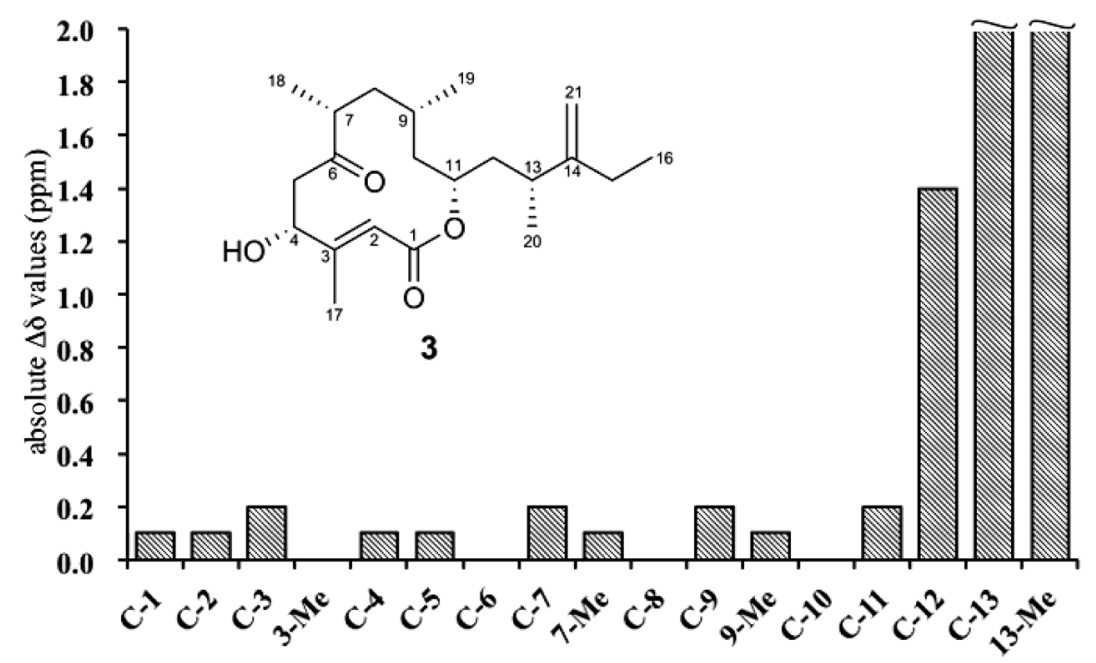

carbon No.

Fig. 5. Chemical Shift Differences $(\Delta \delta)$ between Iriomoteolide-12a (2) and Amphidinolide Q (3)

C-13 of 2 corresponded to those of $\mathbf{3}$. The relatively small coupling constant $(\leq 4 \mathrm{~Hz})$ for $\mathrm{H}-13-\mathrm{H}-14$ suggested a gauche relation between $\mathrm{H}-13$ and $\mathrm{H}-14$. Nevertheless, the relative stereochemistry of the C-13-C-14 bond could not be assigned, because no information on long-range ${ }^{13} \mathrm{C}-{ }^{1} \mathrm{H}$ coupling around the $\mathrm{C}-13-\mathrm{C}-14$ bond was obtained from the HETLOC spectrum.

Iriomoteolide-10a (1) is the first 21-membered Amphidinium macrolide, although several macrolides with odd-numbered, e.g. 13-, 15-, 17-, 19-, 23-, 25-, 27-, and 29-membered, lactone rings were isolated from the marine dinoflagellates Amphidinium species. ${ }^{3)}$ Isoapoptolidin ${ }^{14,15)}$ has been reported as the first example of 21-membered macrolide from natural sources, and corresponds to a ring-expanded isomer of the 20-membered macrolide, apoptolidin. ${ }^{16,17)}$ The interconversion between apoptolidin and isoapoptolidin was described to occur in dilute aqueous solution. However, such isomerization was not observed for $\mathbf{1}$, in alcohol or water. Furthermore, linear fatty acid precursors for $\mathbf{1}$ and $\mathbf{2}$ have not been observed in the extract. Irimoteolide-12a (2) is a new congener of amphidinolide Q (3), containing a 12-membered lactone ring. Compound 1 exhibited cytotoxic activity against human cervix adenocarcinoma HeLa, human B lymphocyte DG-75, and murine hepatocellular carcinoma $\mathrm{MH} 134$ cells $\left(\mathrm{IC}_{50}: 1.5,1.2,3.3 \mu \mathrm{M}\right.$, respectively). Compound $\mathbf{2}$ showed moderate cytotoxicity against DG-75 cells $\left(\mathrm{IC}_{50}: 50 \mu \mathrm{M}\right)$.

\section{Experimental}

General Experimental Procedures Optical rotation and IR data were measured on a JASCO DIP-370 polarimeter and a JASCO FT/IR-5300 spectrophotometer, respectively. NMR data were recorded using $2.5 \mathrm{~mm}$ microcells (Shigemi Co., Ltd., Japan). NMR spectra were measured on a Bruker AMX-500 spectrometer or a Varian-NMR500 spectrometer equipped with a triple resonance PFG Cold Probe or $\mathrm{CH}$ "Xsens" PFG Cold Probe. Chemical shifts were reported in ppm with reference to the residual proton and carbon signals of $\mathrm{C}_{6} \mathrm{D}_{6}\left(\delta_{\mathrm{H}} 7.20\right.$ and $\delta_{\mathrm{C}} 128.0$, respectively $)$ and $\mathrm{CDCl}_{3}\left(\delta_{\mathrm{H}}\right.$ 7.26 and $\delta_{\mathrm{C}} 77.0$, respectively). ESI-MS spectra were recorded on a JEOL JMS-T100LC spectrometer.

Materials A dinoflagellate Amphidinium species (strain
KCA09053) was monoclonally separated from benthic sea sands collected off Iriomote Island, Japan in May 2009.') The voucher specimen was deposited at the Center for Advanced Marine Core Research, Kochi University.

Extraction and Isolation For the cultivation of the dinoflagellate, deep seawater pumped up from $-344 \mathrm{~m}$, offshore of Muroto, Japan, was sterilized by filtration performed using an ultrafiltration membrane, and was then utilized. Cultivation was performed using a $50 \mathrm{~L}$ fermenter (Earth Co., Japan) composed of polycarbonate resin. The culture was maintained in seawater supplemented with $1 \%$ Provasoli's enriched seawater at $25-30^{\circ} \mathrm{C}$ with mechanical stirring at $180 \mathrm{rpm}$ stirring using a MAZELA Z-1300 mechanical stirrer (Tokyo Rikakikai Co., Ltd., Japan) under illumination of approximately $30 \mu \mathrm{mol}$ photons $\cdot \mathrm{m}^{-2} \cdot \mathrm{s}^{-1}$ by fluorescent lights with a $16 \mathrm{~h}: 8 \mathrm{~h}$ light/dark cycle. The cultured algal cells were filtered and concentrated by using a MOLSEP ${ }^{\circledR}$ Fiber FS03-FC-FUS1582 ultrafiltration membrane (Daicen Membrane-Systems Ltd., Japan). The concentrated cells ( $c a$. $2 \mathrm{~L}$ from $50 \mathrm{~L}$ culture) were centrifuged at $3000 \mathrm{rpm}$ at $4^{\circ} \mathrm{C}$ for $10 \mathrm{~min}$ by using a Hitachi CR 22GIII high speed refrigerated centrifuge (Hitachi Koki Co., Ltd., Japan) and then lyophilized using an EYELA FD-511 freeze dryer (Tokyo Kasei Co., Ltd., Japan). The dried algal cells $(30.3 \mathrm{~g})$ obtained from $350 \mathrm{~L}$ of medium were extracted with $\mathrm{MeOH}$-toluene $(3: 1,300 \mathrm{~mL} \times 3)$, and partitioned between toluene $(500 \mathrm{~mL} \times 3)$ and water $\left(\mathrm{H}_{2} \mathrm{O}, 500 \mathrm{~mL}\right)$. The toluene-soluble materials $(7.0 \mathrm{~g})$ of the extract were subjected to silica gel $\mathrm{CC}$ using a gradient elution of $0-2 \% \mathrm{MeOH}$ in $\mathrm{CHCl}_{3}$. The fraction eluted with $\mathrm{CHCl}_{3}-\mathrm{MeOH}$ (98:2) was then chromatographed using an ODS column [Cosmosil $140 \mathrm{C}_{18}$-PREP; eluent: acetonitrile $\left.\left(\mathrm{CH}_{3} \mathrm{CN}\right)-\mathrm{H}_{2} \mathrm{O}, 7: 3\right]$ to give a cytotoxic fraction with $>80 \%$ inhibition of HeLa cells proliferation. The cytotoxic fraction was separated by reversedphase HPLC [YMC-Pack Pro $\mathrm{C}_{18}, 5 \mu \mathrm{m}$, YMC Co., Ltd. (Japan) $10 \mathrm{~mm} \times 250 \mathrm{~mm}$; eluent, $\mathrm{CH}_{3} \mathrm{CN}-\mathrm{H}_{2} \mathrm{O}$ (70:30); flow rate, $2 \mathrm{~mL} / \mathrm{min}$; UV detection at $210 \mathrm{~nm}$ ] to afford $\mathbf{1}[1.4 \mathrm{mg}$, $0.069 \%$, retention time $\left.\left(t_{\mathrm{R}}\right) 24 \mathrm{~min}\right]$. The less polar fraction of the first silica column, eluted with $\mathrm{CHCl}_{3}$ and $\mathrm{CHCl}_{3}-\mathrm{MeOH}$ (98:2), was separated by ODS CC using a gradient of $\mathrm{CH}_{3} \mathrm{CN}$ in $\mathrm{H}_{2} \mathrm{O}$ (70 to $100 \%$ ). The fraction eluted with $70 \%$ aqueous $\mathrm{CH}_{3} \mathrm{CN}$ was purified by reversed-phase HPLC, using the 
conditions described above, to afford $2\left(0.32 \mathrm{mg}, 0.016 \%, t_{\mathrm{R}}\right.$ $17 \mathrm{~min})$.

Cytotoxic Assay A cytotoxicity assay involving HeLa, DG-75, and MH134 cells was performed at $37^{\circ} \mathrm{C}$ in $5 \%$ carbon dioxide, at a density of 5000 cells per well in 96 -well plates, using Dulbecco's modified Eagle's medium (DMEM) containing $10 \%$ fetal calf serum. After $72 \mathrm{~h}$, the number of viable cells was counted using Cell Counting Kit 8 (Dojindo Co., Kumamoto, Japan) according to the manufacturer's instructions. The assay reagent was a tetrazolium compound (WST-8) that is reduced by live cells into a colored formazan product; the absorbance was measured at $450 \mathrm{~nm}$ using a microplate reader (Bio-Rad, U.S.A.). The experiments were repeated in triplicate wells. The viability of the treated groups was estimated as a percentage of that of the control groups. The cytotoxicity is expressed as $\mathrm{IC}_{50}$. 5 -Fluorouracil was used as an authentic sample, and $\mathrm{IC}_{50}$ values against HeLa, DG-75, and MH134 cells were 30,9 , and $0.6 \mu \mathrm{M}$, respectively.

Iriomoteolide-10a (1)

Colorless amorphous solid; $[\alpha]_{\mathrm{D}}^{23}-20 \quad\left(c=0.25, \mathrm{CHCl}_{3}\right)$; IR (KBr) cm ${ }^{-1}: 3443$ (broad), 2920, 1714; ${ }^{1} \mathrm{H}-$ and ${ }^{13} \mathrm{C}-\mathrm{NMR}$ $\left(500 \mathrm{MHz}, \mathrm{C}_{6} \mathrm{D}_{6}\right)$ : Table 1; ESI-MS $m / z: 615.4315[\mathrm{M}+\mathrm{Na}]^{+}$ (Calcd for $\mathrm{C}_{33} \mathrm{H}_{60} \mathrm{O}_{10} \mathrm{Na}, 615.4316$ ).

Iriomoteolide-12a (2)

Colorless amorphous solid; $[\alpha]_{\mathrm{D}}^{23}+37(c=0.16, \mathrm{MeOH})$; UV $\lambda_{\max }(\mathrm{MeOH}) \mathrm{nm}(\varepsilon): 223$ (21300); IR $(\mathrm{KBr}) \mathrm{cm}^{-1}: 3438$ (broad), 2920, 1700; ${ }^{1} \mathrm{H}-\mathrm{NMR}\left(500 \mathrm{MHz}, \mathrm{CDCl}_{3}\right) \quad \delta: 0.68$ $\left(3 \mathrm{H}, \mathrm{d}, J=7.0 \mathrm{~Hz}, \mathrm{H}_{3}-24\right), 0.76\left(3 \mathrm{H}, \mathrm{d}, J=7.0 \mathrm{~Hz}, \mathrm{H}_{3}-23\right), 0.90$ $\left(3 \mathrm{H}, \mathrm{d}, J=7.0 \mathrm{~Hz}, \mathrm{H}_{3}-22\right), 0.90(1 \mathrm{H}, \mathrm{m}, \mathrm{H}-8 \mathrm{~b}), 0.91(1 \mathrm{H}, \mathrm{m}$, $\mathrm{H}-9), 1.03\left(3 \mathrm{H}, \mathrm{d}, J=7.0 \mathrm{~Hz}, \mathrm{H}_{3}-21\right), 1.27(1 \mathrm{H}$, brd, $J=14.0 \mathrm{~Hz}$, $\mathrm{H}-10 \mathrm{~b}), 1.41$ (1H, m, H-10a), $1.42\left(2 \mathrm{H}, \mathrm{t} J=7.0 \mathrm{~Hz}, \mathrm{H}_{2}-12\right), 1.51$ $(1 \mathrm{H}, \mathrm{m}, \mathrm{H}-13), 1.84(1 \mathrm{H}, \mathrm{dd}, J 15.0,8.4 \mathrm{~Hz}, \mathrm{H}-15 \mathrm{~b}), 1.91(1 \mathrm{H}$, m, H-14), $2.05(1 \mathrm{H}, \mathrm{m}, \mathrm{H}-8 \mathrm{a}), 2.06\left(3 \mathrm{H}, \mathrm{s}, \mathrm{H}_{3}-25\right), 2.07(1 \mathrm{H}$, $\mathrm{m}, \mathrm{H}-15 \mathrm{a}), 2.07\left(3 \mathrm{H}, \mathrm{s}, \mathrm{H}_{3}-20\right), 2.12(1 \mathrm{H}, \mathrm{m}, \mathrm{H}-7), 2.12(3 \mathrm{H}$, s, $\left.\mathrm{H}_{3}-19\right), 2.48(1 \mathrm{H}, \mathrm{dd}, J=12.6,5.4 \mathrm{~Hz}, \mathrm{H}-5 \mathrm{~b}), 3.02(1 \mathrm{H}, \mathrm{dd}$, $J=12.6,2.9 \mathrm{~Hz}, \mathrm{H}-5 \mathrm{a}), 4.42(1 \mathrm{H}, \mathrm{m}, \mathrm{H}-4), 5.06(1 \mathrm{H}, \mathrm{m}, \mathrm{H}-11)$, $5.89(1 \mathrm{H}, \mathrm{s}, \mathrm{H}-2), 5.99(1 \mathrm{H}, \mathrm{s}, \mathrm{H}-17) ;{ }^{13} \mathrm{C}-\mathrm{NMR}(500 \mathrm{MHz}$, $\left.\mathrm{CDCl}_{3}\right) \delta: 13.4\left(\mathrm{CH}_{3}, \mathrm{C}-24\right), 14.7\left(\mathrm{CH}_{3}, \mathrm{C}-25\right), 16.8\left(\mathrm{CH}_{3}\right.$, $\mathrm{C}-20), 17.9\left(\mathrm{CH}_{3}, \mathrm{C}-21\right), 19.2\left(\mathrm{CH}_{3}, \mathrm{C}-25\right), 23.2\left(\mathrm{CH}_{3}, \mathrm{C}-22\right)$, $31.8\left(\mathrm{CH}_{3}, \mathrm{C}-19\right), 33.18(\mathrm{CH}, \mathrm{C}-9), 33.23(\mathrm{CH}, \mathrm{C}-13), 33,4(\mathrm{CH}$, C-14), $39.8\left(\mathrm{CH}_{2}, \mathrm{C}-8\right), 40.4\left(\mathrm{CH}_{2}, \mathrm{C}-12\right), 44.6\left(\mathrm{CH}_{2}, \mathrm{C}-5\right), 44.9$ $\left(\mathrm{CH}_{2}, \mathrm{C}-10\right), 46.9\left(\mathrm{CH}_{2}, \mathrm{C}-15\right), 50.7(\mathrm{CH}, \mathrm{C}-7), 73.1(\mathrm{CH}, \mathrm{C}-4)$, 74.2 (CH, C-11), 116.9 (CH, C-2), 124.9 (CH, C-17), 154.9 (C, C-3), 157.9 (C, C-16), 167.7 (C, C-1), 198.7 (C, C-18), 217.0 (C, C-6); ESI-MS $m / z$ : $443.2768[\mathrm{M}+\mathrm{Na}]^{+}\left(\right.$Calcd for $\mathrm{C}_{25} \mathrm{H}_{40} \mathrm{O}_{5} \mathrm{Na}$, 443.2768).

Acknowledgments We thank Satoru Ibuki, Keita Ikebe, and Takahiro Tsushima, Kochi Prefectural Deep Seawater
Laboratory, for the supply of deep seawater and assistance with dinoflagellate cultivation. This study was partially supported by a Grant-in-Aid for Scientific Research (No. 16K08295 to M.T.) from the Ministry of Education, Culture, Sports, Science and Technology (MEXT) of Japan.

Conflict of Interest The authors declare no conflict of interest.

Supplementary Materials The online version of this article contains supplementary materials. Spectral data of compounds $\mathbf{1}$ and $\mathbf{2}$ are available as supplementary materials.

\section{References}

1) Blunt J. W., Copp B. R., Keyzers R. A., Munro M. H. G., Prinsep M. R., Nat. Prod. Rep., 32, 116-211 (2015).

2) Kobayashi J., Tsuda M., Nat. Prod. Rep., 21, 77-93 (2004).

3) Kobayashi J., Kubota T., J. Nat. Prod., 70, 451-460 (2007), and references cited therein.

4) Minamida M., Kumagai K., Ulanova D., Akakabe M., Konishi Y., Tominaga A., Tanaka H., Tsuda M., Fukushi E., Kawabata J., Masuda A., Tsuda M., Org. Lett., 16, 4858-4861 (2014).

5) Akakabe M., Kumagai K., Tsuda M., Konishi Y., Tominaga A., Tsuda M., Fukushi E., Kawabata J., Tetrahedron Lett., 55, 34913494 (2014)

6) Akakabe M., Kumagai K., Tsuda M., Konishi Y., Tominaga A. Tsuda M., Fukushi E., Kawabata J., Tetrahedron, 70, 2962-2965 (2014).

7) Kumagai K., Tsuda M., Masuda A., Fukushi E., Kawabata J., Heterocycles, 91, 265-274 (2015).

8) Tsuda M., Oguchi K., Iwamoto R., Okamoto Y., Kobayashi J., Fukushi E., Kawabata J., Ozawa T., Masuda A., Kitaya Y., Omasa K., J. Org. Chem., 72, 4469-4474 (2007).

9) Oguchi K., Tsuda M., Iwamoto R., Okamoto Y., Kobayashi J., Fukushi E., Kawabata J., Ozawa T., Masuda A., Kitaya Y., Omasa K., J. Org. Chem., 73, 1567-1570 (2008).

10) Matsumori N., Kaneno D., Murata M., Nakamura H., Tachibana K., J. Org. Chem., 64, 866-876 (1999).

11) Kobayashi J., Takahashi M., Ishibashi M., Tetrahedron Lett., 37, 1449-1450 (1996).

12) Takahashi Y., Kubota T., Fukushi E., Kawabata J., Kobayashi J., Org. Lett., 10, 3709-3711 (2008).

13) Hangyou M., Ishiyama H., Takahashi Y., Kobayashi J., Org. Lett., 11, 5046-5049 (2009).

14) Wender P. A., Gulledge A. V., Jankowski O. D., Seto H., Org. Lett., 4, 3819-3822 (2002).

15) Pennington J. D., Williams H. J., Salomon A. R., Sulikowski G. A., Org. Lett., 4, 3823-3825 (2002).

16) Kim J. W., Adachi H., Shin-ya K., Hayakawa Y., Seto H., J. Antibiot., 50, 628-630 (1997).

17) Hayakawa Y., Kim J. W., Adachi H., Shin-ya K., Fujita K., Seto H., J. Am. Chem. Soc., 120, 3524-3525 (1998). 